\title{
ELIMINAÇÃO E DESLOCAMENTOS DA VIOLÊNCIA: UMA TRANSVERSALIZAÇÃO COM AS SOCIEDADE DE CONTROLE DE GILLES DELEUZE
}

\author{
Gisele Gallicchio ${ }^{1}$
}

\begin{abstract}
RESUMO
Este artigo esboça a distinção entre violência de eliminação, assinalando aqueles traços que, conceitualmente, circunscrevem a violência em valores modernos e disciplinares. Ele apresenta uma breve exposição dos componentes constitutivos da Modernidade detectados nas abordagens de Hannah Arendt, Walter Benjamin e Michel Wieviorka. A demarcação da diferença relacionada à eliminação se faz possível a partir do pensamento de Gilles Deleuze e Félix Guattari, considerando os registros e as mutações ocorridas nas sociedades contemporâneas. As propostas de inclusão, participação e educação, acomodadas às demandas das sociedades disciplinares, tornam-se incompatíveis com as condutas promovidas para a reprodução do capital financeiro e das sociedades de controle. Inúmeros eventos vêm assinalando uma percepção diferente da vida e de seus componentes de valoração. A eliminação vem indicar um investimento no processo de subjetivação, que implica a atualização do capital, caracterizando mudanças de um modo de vida. Novas escalas, provocadas pelo devir silício, geram afetos e afecções, colocando em jogo forças demarcadas em acontecimentos, que podem ser expressos pelos verbos eliminar, deletar, exterminar e selecionar. O trabalho procura seguir o percurso da eliminação num processo de desterritorialização da violência, quando incitada pelas práticas de consumo, reterritorializada nas estratégias de controle e absorvida pela subjetividade capitalística. A relação entre eliminar e consumir anuncia não apenas a excitação ao poder de compra e de aquisição de produtos-mercadorias, mas posturas subjetivantes geradas com a equivalência do eliminar aos atos de gastar, destruir, liquidar. A eliminação passa a engendrar as sociedades de controle que, através das máquinas comunicacionais e informacionais, investem no deletar. Ações e as condutas, sobrecodificadas em cotações e índices, reproduzem os mecanismos do capital financeiro numa espécie de pedagogia exercida nas redes sociais e nos jogos digitais. As estratégias intensificam-se, modulando os eliminar e o deletar em exterminar. Elas permeiam diferentes territórios existenciais: do funcionamento das empresas às chacinas escolares. Os vetores de desterritorialização apontam a potência de criação da eliminação através do selecionar, que, através de uma dimensão ética e estética, demarca as linhas de fuga capazes de afirmar a diferença e de produzir de um novo modo de vida.
\end{abstract}

Palavras-chave: Consumo. Modos de subjetivação. Sociedades de controle. Mutações do capitalismo.

\begin{abstract}
This article broach the distinction between violence and elimination, noting those traits that conceptually circumscribe violence in modern and disciplinary values. It presents a brief summary of the constituent components of Modernity detected in the approaches of Hannah Arendt, Walter Benjamin and Michel Wieviorka. The demarcation of the related elimination difference is made possible from the thought of Gilles Deleuze and Felix Guattari, considering the changes occurring in contemporary societies. Proposals for inclusion,
\end{abstract}

\footnotetext{
${ }^{1}$ Doutora em Educação pela Universidade Federal do Ceará (UFC). E-mail: gisoaresgal@gmail.com
} 
participation and education, accommodated the demands of disciplinary societies, become incompatible with the behaviors promoted for reproduction of financial capital and control societies. Numerous events have been pointing out a different perception of life and its valuation components. The elimination comes indicate an investment in the subjective process, which involves upgrading the capital, featuring changes of a way of life. New scales, caused by becoming silicon, generate feelings and affections, putting at stake demarcated forces in events which can be expressed by the verbs "to eliminate", "to delete", "to exterminate and "to select". The work seeks to follow the route of elimination in the process of dispossession of violence when prompted by consumer practices, captured in control strategies and absorbed by the capitalistic subjectivity. The relationship between remove and consume announces not only the excitement purchasing power and the acquisition of products, goods, but subjective postures generated by the equivalent of eliminating the acts of spending, destroy, liquidate. The elimination happens to engender societies of control, through the communication and information equipment, invest in "to delete". Actions and behaviors, coded in price and index, reproduce the mechanisms of financial capital in a kind of pedagogy exerted on social networks and digital games. The strategies themselves intensify, modulating "to eliminate" and "to delete" to "to exterminate". They permeate different existential territories: the operation of enterprises to school massacres. The dispossession of vectors point to the power of creation of elimination through select, which, through an ethical and aesthetic dimension, marks the escape lines capable of asserting a difference and to produce a new way of life.

Keywords: Consumption. Subjectivity modes. Control societies. Capitalism changes.

\section{A MODERNIDADE E A MORAL}

A Modernidade é definida por Jean Baudrillard (1982) como um modo de civilização que se distingue das formações organizadas pela tradição. Este modo impõe-se como uno, homogêneo, com irradiação mundial a partir do ocidente, estendendo-se por todos os domínios: jurídico-político, moral, técnico-científico, estético, social, econômico, configurando uma categoria geral ou um imperativo cultural. Suas características baseiam-se na representação, sustentadas pelo sujeito e pela razão, estipulando os critérios e princípios de conhecimento e de determinação da verdade, a certeza assegurada pela ciência, a fé no progresso e no bem-estar social, a produtividade e a humanidade dirigidas à missão civilizatória. O autor localiza a gênese da Modernidade no século XVI, quando ocorre a transição para o capitalismo e o Renascimento (cultural e comercial). Ao longo dos séculos XVII e XVIII, constroem-se os fundamentos filosóficos e políticos que fundamentam as ideias de representação, igualdade e participação, demarcadoras de uma sociedade emergente e contraposta ao poder monárquico e ao mundo feudal. A instauração do Estado Liberal Moderno, através da Constituição, corresponde à salvação formal do indivíduo e assegura a propriedade pela fronteira e regulação entre esferas pública e privada. Do ponto de vista

\begin{tabular}{|l|l|l|l|l|}
\hline Govista Dialactus & Ano 2 & n.7 & Setembro-Dezembro 2015 & p. 127-146 \\
\hline
\end{tabular}


cognitivo e psicológico, exalta-se o sujeito de autonomia e de consciência, assim como o indivíduo propagado pelo romantismo, que manifesta conflitos pessoais, interesses privados, emoções, paixões e desejos. O traço civilizatório é reforçado pela dimensão histórica e linear do tempo, que sinaliza a evolução da humanidade através de uma projeção sucessiva e universalizante. Somente no século XIX, a Modernidade institui-se como uma prática social e um modo de vida, permeando o cotidiano, as condutas, através da normatização dirigida à produtividade pela combinação de forças, de espaço e de tempo cronométrico. Esta concepção de vida moderna gera um mundo antropomorfizado, que faz uso do atributo humano para determinar seu valor, bem como para definir medidas e leis adequadas à sua reprodução, estabelecendo uma ordem moral de mundo. Conforme destaca Santiago (2009), a natureza é colocada a serviço do homem, instituindo a finalidade como traço moral. Tal ordem atribui às sociedades os fundamentos filosóficos centrados no Bem, nos fins (teleologia), no nãoegoísmo (fraternidade), na livre vontade (liberdade), conferindo ao projeto moderno de sociedade seus contornos morais.

A noção de representação, proposta por Kant, possibilita perceber a articulação entre cognição, moral e vida. O filósofo enfatiza a condição de ser racional como principal atributo do ser, valorizando no traço humano o fundamento que justifica e organiza a maneira de viver. Pela representação e pelo sujeito kantiano, ocorre uma espécie de conversão, em que o sujeito transcendental passa à condição necessária da vida, porque a priori e universal. Deleuze (p. 24) destaca na tese kantiana que: “os fenômenos estão necessariamente submetidos às categorias, de tal modo que, pelas categorias, somos os verdadeiros legisladores da Natureza". A lei moral determina o ser racional como fim extensivo ao mundo sensível, exaltando a supremacia da razão sobre a natureza. A liberdade, decorrente da autonomia do sujeito cognoscente, também define o lema político e filosófico da sociedade moderna resultante da razão e condicionada a ela. Aposta-se na constituição do indivíduo como ser moral e consciente a ser educado de acordo com um modelo de participação social. A vida é restringida a uma dimensão moral que determina uma relação de causalidade entre razão e liberdade, suportando o imperativo categórico ${ }^{2}$, o qual faz do dever um meio e um fim, pois o $\mathrm{Bem}^{3}$ e a liberdade estão condicionados à obediência da lei. Trata-se de uma obediência necessária diante da hierarquia sustentada pelo conhecimento, estabelecendo a

\footnotetext{
${ }^{2}$ Marcondes (2007, p. 94) assinala o imperativo categórico de Kant, que determina "age somente de acordo com a máxima pela qual possas, ao mesmo tempo, querer que ela se torne uma lei universal.

${ }^{3}$ Deleuze (s/d, p. 47) destaca a ideia de proporção entre felicidade e moralidade como Bem Soberano, que pressupõe o acordo entre natureza sensível e natureza suprassensível, conformando a totalidade do objeto da razão pura prática.
}

\begin{tabular}{|l|l|l|l|l|}
\hline Qevista Dialectus & Ano 2 & n.7 & Setembro-Dezembro 2015 & p. 127 - 146 \\
\hline
\end{tabular}


justiça pela conformidade com a ideia. No pensamento de Kant, o homem, convertido em sujeito transcendental, ganha proporções quase divinas, que autorizam sua sobreposição à natureza em função da lei moral com seus fins racionais. Nesta ordem, o estatuto humano tem maior valor e corresponde à própria vida. Uma vida que passa a ser considerada patrimônio individual e coletivo.

A condição humana, ao reger as ações das existências particulares, determina a humanidade como destino e totalidade através da realização histórica que representa a razão absoluta. Vaz (1992, p. 19) assinala que, para Hegel, a filosofia deve cumprir a "exigência da transcrição no conceito do tempo histórico daquele mundo de cultura que colocou a Razão no centro do seu universo simbólico". Além de dar razão à existência, ela anuncia o "advento, na História do Ocidente, do indivíduo que aceita existir na forma da existência universal ou da existência regida pela Razão".

O termo humanidade passa a apresentar um caráter universalizante, significando tanto a natureza racional do homem, presente no imperativo categórico de Kant, como também os princípios essenciais da espécie, que transcendem aos princípios individuais. Sua relação com a história determina o sentido de uma ordem universal seja como consciência, seja como estágio social, seja como evolução biológica. A ordem moral de mundo sinaliza que, nas sociedades disciplinares (modernas), o humano e/ou a humanidade estabelecem finalidade e medida para todas as coisas, derivando em noções de justiça, definindo obrigações e delitos com suas respectivas punições. A noção de violência está inserida neste tabuleiro moral, ao operar como signo ${ }^{4}$. Sucintamente, a violência corresponde à força absorvida como delito que fere a lei e a moral. Encodificada e justificada pela desigualdade social, ela sinaliza a exclusão de acordo com uma moral constitutiva do sujeito, enquanto indivíduo dotado de direitos e deveres, apostando na educação (formal e informal) como alternativa de apaziguamento dos conflitos pela promessa de futuro de uma vida melhor. Pautada pela representação, pelo sujeito e pela teleologia, a violência aparece ora como delito, ora como conflito. Nos dois casos, envolve o sentido histórico pela noção de obstáculo a um modo de civilização ou, ainda, pela concepção dialética de conflito estruturante e motor do progresso social.

\section{TRAÇOS MORALIZANTES DA VIOLÊNCIA}

\footnotetext{
${ }^{4}$ Os conceitos de violência, usualmente, desconsideram a concepção nietzscheana, pautada pela assimetria das forças em jogo. Eles conformam signos abstrativos, imperativos e interpretativos, que isolam certos elementos em suas definições generalizantes, prescrevendo soluções e condutas normativas, bem como valorizando crenças em modelos representativos.

\begin{tabular}{|c|c|c|c|c|}
\hline Rovista Dialectus & Ano 2 & n.7 & Setembro-Dezembro 2015 & p. $127-146$ \\
\hline
\end{tabular}
}


É possível localizar, nas construções filosóficas, alguns elementos recorrentes nos discursos vigentes sobre violência, bem como articular traços comuns que cruzam as noções de Benjamin, Arendt e Wieviorka. Observa-se que suas produções respondem a circunstâncias históricas diferentes, percorrendo a efetivação da violência em diversas direções.

Arendt traz como contorno de sua problematização o contexto do pós-guerra, os efeitos da bomba atômica, a Guerra do Vietnã, os processos de descolonização e as práticas da esquerda, que recorrem a meios violentos de resistência. A análise pende para uma perspectiva restauradora de participação política pautada pelo poder. Ela não apenas distingue, mas separa poder de violência. O poder corresponde à representação, envolvendo tanto um governo representativo, quanto a voz de um grupo ou de um coletivo no jogo de interesses. Esta definição reduz-se à esfera jurídico-política, circunscrita por um mecanismo de participação social fecundado no Iluminismo. Neste âmbito, indivíduos iguais em direitos e deveres observam as fronteiras entre o público e o privado, utilizando os recursos políticos adequados para garantir o bem-estar coletivo. Arendt (2009, p.57) acredita que "sob condições de um governo representativo supõe-se que o povo domina aqueles que governam [...]", por isso "instituições políticas são manifestações e materializações de poder" sustentadas pelo povo. Ela (p. 97) argumenta que o "ser esclarecido vai contra a natureza do interesse próprio" para priorizar a garantia da expectativa de vida do mundo público.

A primeira distinção que a autora propõe entre poder e violência diz respeito à adesão. O poder depende da representação de uma maioria, ao passo que a violência, além de um número insignificante de adeptos, opera assentada em implementos, em instrumentos tecnológicos orientados para majoração do vigor individual. O poder compreende a habilidade humana de agir em concerto. Ele pertence a um grupo e depende da conservação desta união. Como essência de todo o governo, é um fim em si mesmo, porque assegura a condição que capacita um grupo de pessoas a pensar e agir em termos de categorias de meios e fins. A autora (p.60-70) destaca que o poder, ao diferir dos meios, "não precisa de justificação". Inerente à própria existência das continuidades políticas, ele requer legitimidade, cujo reconhecimento da maioria efetiva-se pela participação e representação.

Arendt procura desvincular força de violência. A primeira não tem correspondência moral, compreendendo uma dimensão física, uma energia considerada força mensurável. A segunda é analisada pelo viés moral e impede o exercício político. A violência não se enquadra em uma conduta de fundo moral, apesar de pertencer à ordem racional por instituir

\begin{tabular}{|c|c|c|c|c|}
\hline Rovista Dialectus & Ano 2 & n.7 & Setembro - Dezembro 2015 & p. $127-146$ \\
\hline
\end{tabular}


meios que operam cálculos com objetivos precisos. A ordem moral é reservada para a dimensão política, para a esfera do poder. A violência é instrumental e destrói o poder. Entre suas causas, destacam-se a falta - como ausência ou supressão de poder - e/ou a "frustração da faculdade de agir no mundo moderno". Arendt refuta a concepção hegeliano-marxista, na qual poder e violência são termos que se contrapõem numa relação dialética em direção à transformação e ao desenvolvimento, correspondendo a opostos que não se destroem, mas promovem a transformação. Esta concepção caracteriza o conflito como motor da história, cuja superação das contradições comporta uma síntese. A recusa da dialética concentra-se no argumento de que "poder e violência são opostos, onde um domina absolutamente, o outro está ausente". A violência aparece "onde o poder está em risco", ocorrendo uma inversão de cálculos dos meios e fins: "os meios de destruição, agora determinam o fim - com a consequência de que o fim será a destruição de todo o poder". Em termos metodológicos, ao refutar a negação dialética, Arendt apresenta uma inspiração weberiana, abordando a violência por uma ótica racionalista com base nos cálculos dos meios e dos fins ${ }^{5}$. A concepção "ideal” da estrutura de poder está condicionada ao consenso que, através do "agir em concerto", fundamenta uma teleologia, pois defende um certo equilíbrio de interesses manifesto como condição para o futuro. Ao admitir que poder e violência estão combinados e não existem separadamente, ela retoma os opostos, agora, inversamente proporcionais e inerentes à vida política. Resumidamente, na definição de Arendt, a violência é instrumental, racional (humana) e eficaz para alcançar um fim que a justifique. Seus objetivos não promovem história, nem progresso, pois ela configura uma arma da reforma e não da revolução. A autora critica acirradamente a violência como uma forma de resistência revolucionária.

Benjamin dialoga com Arendt ao apontar a violência a partir das relações com o direito e a justiça, implicando relações éticas. Nesta perspectiva, a violência constitui um meio para determinados fins que podem ser justos ou injustos. Ele questiona se a violência em si qualifica-se em uma moral. Há um esforço em escapar do viés moralizante, suspendendo o critério de justiça para definir a violência. $\mathrm{O}$ autor vê uma impossibilidade analítica sob o crivo do direito (tanto do direito natural, quanto do direito positivo). Para o direito natural, a violência é considerada um produto da natureza. O poder é um dado natural que encontra eco na seleção proposta pela biologia darwiniana, cuja violência consiste em um meio adequado

\footnotetext{
${ }^{5}$ Arendt critica a definição de Estado de Weber, que compreende "o domínio do homem pelo homem baseado nos meios de violência legítima". A legitimidade não impede a existência da violência exercida pelo domínio político. Para ela, a violência exige justificação, ao contrário do poder, que demanda legitimação.

\begin{tabular}{|c|c|c|c|c|}
\hline$\rightarrow$ & Ano 2 & $\mathrm{n} .7$ & Setembro - Dezembro 2015 & p. $127-146$ \\
\hline
\end{tabular}
}


para todos os fins vitais. O critério delimitador do estabelecimento do direito é definido pela "justiça dos finns". Se os fins são justos, os meios tornam-se legítimos. O direito positivo, por sua vez, concebe o poder como uma criação histórica, invertendo a relação anterior. Ele avalia a legitimidade dos meios independentemente dos fins (justos ou injustos).

Benjamin dispensa a argumentação do direito positivo e do direito natural, relativiza a distinção entre poder legítimo e ilegítimo, bem como critica a função do poder determinada pelas relações jurídicas que erige o sujeito de direito, garantindo a primazia do jurídico e do próprio direito sobre o indivíduo. A passagem do indivíduo ao sujeito de direito ocorre quando o primeiro, portador de direito natural, recebe um estatuto jurídico, o qual fixa limites e recobre todas as áreas da vida em conformidade com os seus fins (jurídicos). Esta nova condição visa controlar o poder do indivíduo que apresenta um perigo de subversão da ordem jurídica. Seu enquadramento em sujeito constitui um mecanismo de contenção. A violência passa a ser entendida como ameaça ao direito.

A análise de Benjamin, na esfera do direito, sinaliza as contradições daquelas situações em que os sujeitos jurídicos sancionam a violência. Sua abordagem aponta o Direito como uma prática de poder que ativa funções violentas para fazer cumprir a lei. Arendt separa a violência da ordem jurídico-política ao tratá-la como algo exterior cuja natureza e os objetivos anulam o poder. Benjamin considera o poder um meio divido em "poder instituinte e poder mantenedor do direito". O contrato impõe uma coerção ligada à solução, que adquire o estatuto de lei e distribui uma ação violenta para as partes envolvidas. A aplicação de critérios justos equivale à distribuição de penalidades sob a forma de concessão das partes. Em diferentes circunstâncias, Benjamin (p. 169-170) derruba a possibilidade do poder ser inibidor da violência. Sua aposta dirige-se a um acordo pacífico, que aciona registros exteriores ao domínio jurídico e aos procedimentos contratuais. Soluções não-violentas para conflitos investem na ordem subjetiva ${ }^{6}$ em detrimento da lei, a qual é entendida como manifestação objetiva. Elas comportam um método "que por princípio é superior ao da arbitragem, uma vez que se situa além de toda a ordem jurídica e, portanto, além da violência”. Para o autor, meios legítimos e ilegítimos de toda espécie são expressão da violência, distinguindo-se da articulação de meios puros não-violentos resultantes da conversa como "técnica de mútuo de entendimento civil." A linguagem compreende uma esfera de entendimento humano inacessível à violência. O investimento no diálogo e na linguagem

\footnotetext{
${ }^{6}$ A “atenção do coração, a simpatia, o amor pela paz, a confiança e outras qualidades a mais" são pressupostos subjetivos dos meios não-violentos. (Ibidem, $p .168$ ).

\begin{tabular}{|c|c|c|c|c|}
\hline Rovita Dialectus & Ano 2 & n.7 & Setembro - Dezembro 2015 & p. $127-146$ \\
\hline
\end{tabular}
}


converge para a proposta de "agir em concerto", de Arendt, e para a concepção de "consenso" viabilizada pelas regras do discurso presente no "agir comunicativo" de Habermas. Entretanto, o modo de apreender e implementar tal diálogo ou conversa difere tanto dos aspectos teleológicos (Arendt), quanto dos traços normativos (Habermas). Benjamin procura ultrapassar a dimensão jurídico-política do poder, abrindo uma possibilidade de análise associada aos processos de subjetivação. Ele suspeita da existência de outros tipos de poder, além daqueles localizados na esfera do direito ${ }^{7}$, abrindo fendas que levam a desconfiar da versão moralizante, a qual julga a violência uma estrangeira aos cânones modernos.

O estudo de Wieviorka recobre outra conjuntura, abarcando as transformações que mudaram a geografia do mundo com o desaparecimento do bloco socialista, implicando a alteração das relações de forças. O processo de globalização, marcado pelo fim da Guerra Fria, pelo desmembramento da União Soviética e pela queda do muro de Berlim, produz a diluição do conflito mundial organizado em dois blocos com sistemas econômicos antagônicos e projetos político-sociais diferentes. Tal tensão, que produzia um equilíbrio, desfaz-se com o desmembramento do bloco socialista. As guerras civis "adquirem outra característica e uma nova situação autoriza a privatização da violência que ganha um papel instrumental e econômico.” Há uma multiplicação das violências identitárias assinaladas pelas guerras étnicas, bem como "o comércio de armas e sua difusão quase viral alimentando a guerra ou a guerra civil, o terrorismo, o crime organizado e a delinquência" (Wieviorka, 2005, p. 36). Na nova ordem mundial, o conflito de classes descaracteriza-se e as ações violentas intensificam-se diante da perda de suas causas, adquirindo outras significações no processo de subjetivação contemporâneo. Estas mudanças são mapeadas através das manifestações de violência urbana e das práticas terroristas.

O conceito de violência é revisado e classificado em duas direções ligadas ao sentido histórico. A primeira possui um papel revolucionário, em que o conflito atua como propulsor. Ela é legítima porque incita o nascimento de uma nova sociedade, atuando como instrumento de movimento social que arrebata e destrói as formas políticas coaguladas da sociedade vigente, levando à sua superação. A segunda atribui um caráter negativo à violência por impor-se como um obstáculo ao processo civilizatório. Ela é tratada como um entrave à realização do progresso social. Wieviorka (2005, p.20) constata os limites dos dois modelos explicativos frente ao crescimento da violência no mundo de hoje. Ele propõe "pensar a

\footnotetext{
${ }^{7}$ Há, aqui, uma aproximação da questão disparada por Foucault que desemboca na microfísica do poder, a qual tem sustentação na concepção nietzschiana de moral e de poder.
} 
violência com a ajuda de um novo paradigma", a fim de renovar as categorias de análise, considerando "as profundas modificações que resultam inadaptadas, insuficientes ou secundárias às categorias anteriores". Estas modificações apresentam "um ritmo aterrorizante, alterando a paisagem no mundo onde vivemos em todos os níveis planetário, internacional, social, local, individual".

Sua análise tem por base conceitual a noção de sujeito definido pela "capacidade de constituir-se a si próprio, de proceder a escolhas, de produzir sua própria existência." (Wieviorka, 2006, p.203). Ele recusa os autores contemporâneos, que rompem com esta categoria para pensar os acontecimentos, sustentando sua construção na retomada do par "sujeito e conflito". O conflito, que compreende dialeticamente forças opositivas, tem vital importância na estruturação e constituição do sujeito no universo social. Como relação estruturada de uma maneira mais ou menos estável e durável, apresenta uma proporcionalidade de forças que dispõe os atores sociais em adversários e não em inimigos. “O conflito pressupõe adversários suscetíveis a estabilizar sua relação numa institucionalização, na instauração de regras de negociação, de modalidades que permitem conjugar a manifestação de um laço entre atores e opositores” (Wieviorka, 2005, p.25). Esta relação, fundamentada na contradição, comporta uma certa simetria ${ }^{8}$ num movimento de tensão necessário à organização das sociedades. A violência ocorre pela ausência do conflito, quando não existe mais espaço para negociação. Ela é sua negação e implica em ruptura da relação entre os pares contrapostos, tomando o adversário como inimigo, condição que justifica sua destruição. Wieviorka aplica a fórmula de proporcionalidade de Arendt, substituindo os termos "poder e violência" pelo "conflito e violência". Assim, quanto maior a violência, menor o conflito. O desaparecimento do conflito e o aumento da violência servem de balizadores da atual crise social, política e econômica, indicando a desorganização das instituições e seus prolongamentos políticos, visto que o conflito consiste em elemento estruturante das relações.

A supressão do conflito, decorrente da desestruturação da sociedade industrial e do esmorecimento da cultura da classe trabalhadora, leva à perda de sua referência identitária, sua utilidade e seu valor no universo globalizado. A categoria de classe deixa de orientar as posições do sujeito neste processo. A violência urbana desconecta-se de todo o conteúdo, de toda a carga realmente social numa espécie de decomposição. Os indivíduos desligam-se da

\footnotetext{
${ }^{8}$ A inexistência desta simetria das forças em jogo impede a estruturação de uma relação que exige pares e pressupõe dicotomias. 
sociedade com o desaparecimento de um dos pares relacionais. Wieviorka aponta algumas alternativas para evitar a violência, recorrendo à necessidade de restauração do sujeito, destacando a inclusão através de políticas de reconhecimento econômico, social e racial; a equidade e reconhecimento cultural para restaurar a comunicação; a transformação da violência em conflito, encorajando os atores às trocas e ao reconhecimento pelo exercício de alteridade; a reparação da delinquência de menores pela responsabilização e pelo reconhecimento de normas; a retomada do sujeito como referência teórica, para além classificação de vítima e de protagonista; pautando a inserção das subjetividades nos sistemas sociais, políticos e culturais.

\section{RECORRÊNCIAS E ABERTURAS: DA VIOLÊNCIA À ELIMINAÇÃO}

O breve percurso entre os autores vislumbra três componentes constantes nos discursos acerca da violência: sujeito, poder-representação ${ }^{9}$ e futuro, sustentando a ordem moralizante moderna. Seus argumentos explicativos variam com a ênfase ou a justaposição a outros elementos. A violência define-se pela negação de um dos três termos. Ela pode ser assinalada por um sujeito ausente, incompleto, inadequado; por um poder suprimido, opressivo, coercitivo; pela inexistência de um futuro, de um fim, de uma teleologia. Benjamin, Arentd e Wieviorka, mesmo nas situações em que pretendem romper com os referentes moralizantes, apresentam definições ainda arraigadas a um viés moral, rebatendo estes termos numa espécie de insuficiência para expressar os acontecimentos.

O esforço deste artigo é localizar os componentes que impedem pensar as atualizações e detectar uma expressão diferente da abordada pela violência e pela representação, apontando para a prática da eliminação nas relações de poder contemporâneas.

A subjetividade, para Deleuze e Guattari, é social. Ela não supõe um sujeito que se opõe a um objeto, pautando a distinção subjetividade e objetividade, mas fabrica sujeitos, indivíduos normalizados, enquadrados em referentes, cujos territórios identitários garantem uma mais-valia de poder pela produção de condutas, comportamentos, sonhos, desejos, práticas cotidianas que investem no "Eu", assegurando a reprodução do capital. A subjetividade capitalística reforça a noção "propriedade", estendendo-a para além da posse dos meios de produção. Com isso, ganha dimensões micropolíticas, moleculares, tornando todas as relações monetarizáveis, quantificáveis através de um equivaler generalizado, que

\footnotetext{
${ }^{9}$ Poder-representação corresponde à noção foucaultiana de poder jurídico-político.

\begin{tabular}{|c|c|c|c|c|}
\hline Revista Dialectus & Ano 2 & n.7 & Setembro - Dezembro 2015 & p. $127-146$ \\
\hline
\end{tabular}
}


permeia e se reproduz nas esferas familiares, domésticas, amorosas, escolares, partidárias, esportivas, religiosas..., fazendo uso da "apropriação" para sustentar o reconhecimento e a identidade.

Deleuze e Guattari aproximam-se de Foucault, quando este demarca a capilaridade do poder, indicando a eficácia do dispositivo disciplinar em produzir sujeitos que são, ao mesmo tempo, agentes e efeitos de poder, quer dizer, resultantes de um assujeitamento que faz o poder circular, tornando-o positivo numa economia dirigida à distribuição de espaço, tempo e energia para aumento da produtividade. Daí a importância da maquinaria disciplinar e normalizadora pertinente às instituições modernas, que adestra e dociliza os corpos, efetivando um modo de vida.

O conceito de violência, ao ser dissociado de um conjunto de condutas e de ações regulares, acarreta transformações indicativas de um estilo de vida. Quais são esses deslocamentos? Que relações de forças eles engendram? Que valores estão se estabelecendo nessas relações? Há uma desterritorialização da moral moderna? Trata-se de uma passagem para constituir uma outra moral? Existe uma ética possível nessa passagem? Como seus elementos ligam-se aos processos de produção da subjetividade? Essas indagações forçam pensar as mutações ocorridas nas sociedades contemporâneas para além das críticas e/ou propostas de erradicação da violência que se encontram amarradas aos projetos modernos de sociedade. Pontas de desterritorialização escapam ao enquadramento da violência pela moral, indicando novas práticas e novas condutas alinhadas a constrangimentos e a coerções, que investem no extermínio da vida e desembocam em percepções e potências de novos modos de existência. Nessa direção, é proposto o conceito de eliminação, buscando percorrer os acontecimentos e suas atualizações ${ }^{10}$.

Condutas instituídas por um tipo de exercício de aniquilamento desvinculado da noção de justiça apontam para o desprendimento da ordem moral moderna, ganhando expressão em inúmeros territórios, valendo-se de uma gama de significados no desenho de novos contornos produzidos na subjetividade vigente. Estas condutas são incitadas e exercidas por mecanismos de valoração e de demarcação de regras, cujo caráter imperativo orienta-se para a supressão dos obstáculos a fim de aumentar a eficácia de um sistema.

${ }^{10}$ Esse conceito foi trabalhado na tese intitulada "Eliminação: uma desterritorialização da violência (linhas transversais aos territórios escolares", defendida no Programa de Pós-Graduação de Educação da Universidade Federal do Ceará (UFC) sob orientação do Prof. Dr. Sylvio Gadelha (UFC) e co-orientação do Prof. Dr. Luiz Orlandi (Unicamp) em 2012.

\begin{tabular}{|l|l|l|l|l|}
\hline Q Rovista Qialectus & Ano 2 & n.7 & Setembro-Dezembro 2015 & p. 127-146 \\
\hline
\end{tabular}


A eliminação, quando engrendrada à produção da subjetividade, traz componentes capazes de delinear um problema ligado a um modo de vida contemporâneo. Deleuze (1999, p. 10) sublinha em Bergson a relação entre problema e vida. Nela, o problema "tem suas raízes para além da história, na própria vida e no impulso vital: é a vida que se determina essencialmente no ato de contornar obstáculos, de colocar e resolver um problema". O problema deste trabalho parte de um incômodo, um desassossego, um deslocamento (um distanciamento do que é familiar, se tomado do ponto de vista antropológico), encontrando-se inseparável do vivido, indicado por um descompasso entre os discursos vigentes acerca da violência e o corte que delineia a eliminação com traços das sociedades atuais. Tal estranhamento, ao se tornar Interessante, dispara um problema filosófico para Deleuze e Guattari (1992, p. 108), pois a "filosofia não consiste em saber, e não é a verdade que [a] inspira, mas categorias como as do Interessante, do Notável ou do Importante [...]”. O Interessante carrega uma capacidade de afetar, uma atenção para os componentes, que colocados em relação e em movimento, podem lançar uma suspeita, traçar linhas, construir um problema, erigir um plano, criar um conceito. Um problema é construído, é inventado pelo traçado de um plano a ser povoado por conceitos na produção de sentido do acontecimento. Os conceitos dizem dos acontecimentos, assim como encarnam e se efetivam nos corpos. $\mathrm{Na}$ trajetória do pensamento-mundo, conceito e coisa, pensamento e vida não comportam modelos, nem abstrações. A vida é intensiva, o pensamento imanente. O conceito é talhado pela coisa, convém somente a ela e não é mais amplo do que aquilo que ele deve dar conta. Não há pretensão projetiva, preditiva, nem universal. Trata-se da singularidade do acontecimento em que se atribui a cada coisa sua medida e sua intensidade. Um conceito, composto por elementos heterogêneos, se constrói e se modifica pelos movimentos e pelas linhas que se encontram no percurso desse acontecimento em devir. Os conceitos devem ter uma coerência entre si, mas tal coerência não deve vir deles. Deve receber sua coerência de outro lugar.

As forças implicadas nas mudanças de um modo de vida tensionam a pensar que a eliminação vem assinalar um novo sentido dos acontecimentos expresso pelo eliminar, deletar, exterminar e selecionar. Em Lógica do Sentido, Deleuze (p. 22) considera que o sentido é o acontecimento expresso pelo verbo. $\mathrm{O}$ "expresso não se parece de forma nenhuma com a expressão", sendo o sentido o "atributo da coisa" que é o verbo ou, antes, "o acontecimento expresso por este verbo". Sentido e acontecimento, capitalismo e esquizofrenia demarcam o uso e os limites (relativo e absoluto) produtores dos deslocamentos que ampliam 
o capitalismo. Tais deslocamentos são apreendidos na articulação do consumo com o controle.

A eliminação é apontada por Lyotard (1988) na produção dos enunciados científicos com o atrelamento do conhecimento às exigências do mercado. $\mathrm{O}$ autor detecta a dissociação entre conhecimento e verdade, marcando a eliminação como um novo princípio que rege a ciência. A produção do conhecimento científico desconecta-se do critério moral de verdade e de justiça. A discussão sobre ciência, verdade e conhecimento reaparece em sua análise acerca do princípio de deslegitimação. Esse princípio condiciona o conhecimento ao controle de contexto, indicando a associação da produção do saber ao mercado. Ao assinalar a passagem da legitimação filosófica da ciência e do conhecimento, baseado no princípio da metalinguagem universal, para a pluralidade de sistemas formais e axiomáticos, que fazem uso das técnicas na administração das provas, destaca uma mudança de princípio, em que a otimização das performances sustenta a pertinência dos enunciados segundo critérios do desempenho e da eficiência em detrimento do verdadeiro, do justo e do belo. A legitimação do conhecimento ocorre pelo controle de contexto correspondente à melhoria das performances. Os aparelhos, que otimizam as performances, exigem suplemento de despesa, resultando na equação: riqueza, eficiência e verdade. O capitalismo vem atuar na solução do problema científico de crédito à pesquisa, diretamente nas empresas e, indiretamente, com a fundação de instituições de pesquisa privadas, estatais ou mistas.

Lyotard (p. 83 e 85) afirma que o "Estado e/ou a empresa abandona o relato idealista ou humanista para justificar a nova disputa: o poder”. A relação entre ciência e técnica inverte-se, "o critério do bom desempenho é explicitamente invocado pelas administrações para justificar a recusa de apoiar este ou aquele centro de pesquisa”. Resumidamente, desaparecem os fundamentos filosóficos da Modernidade baseados na razão, na verdade e no sujeito que conferem ao conhecimento um caráter universal. A ciência não mais se legitima pelo critério da verdade, mas pelo critério do desempenho. Não interessa saber se é verdadeiro ou falso, mas eliminar o erro a fim de assegurar maior velocidade e eficácia dos resultados. Capital e conhecimento estão intimamente ligados e destinados às demandas de mercado com o abandono do critério de verdade para a legitimação do conhecimento. O autor (p. XII) acentua que "o importante agora não é afirmar a verdade, mas sim localizar o erro no sentido de aumentar a eficácia, ou melhor, a potência”. Esta ruptura, indicada na esfera da produção de conhecimento que envolve o registro dos enunciados científicos, perpassa as relações cotidianas, sinalizando o desprendimento dos critérios balizadores da moral moderna e a

\begin{tabular}{|l|l|l|l|l|}
\hline Govista Dialectus & Ano 2 & n.7 & Setembro-Dezembro 2015 & p. 127-146 \\
\hline
\end{tabular}


conformação de outras formas de constrangimento, outras regras para a avaliação da produção e das condutas.

As condutas, regidas pela eficácia, ao passarem pelos territórios existenciais, instituem práticas que esboçam novos valores. Tais práticas usam da eliminação dos entraves, apostando no aumento das velocidades, intervindo no modo de vida e conferindo uma transmutação da violência. A violência separa-se da norma constituída pelo dispositivo disciplinar, diluindo-se em comportamentos dignos de reconhecimento e prestígio. Eliminar começa a se tornar palavra de ordem. O erro passa a corresponder a qualquer obstrução ao aumento de velocidade e à realização do melhor desempenho, ganhando extensão nos diversos segmentos, permeando as condutas e as práticas moleculares. Ações, que dizem respeito a esses ideais de eficácia e desempenho, em que a eliminação vem a ser a forma de garantia de melhores resultados em menores tempos, atravessam os sistemas informatizados, as atividades profissionais, as relações pessoais. Nas diferentes condutas, problemas, pessoas, coisas que constituem obstáculos e atrasam resultados são eliminados, apagados, extintos. As máquinas comunicacionais engendram esses movimentos em diversos eventos. A veiculação asséptica, com transmissão via satélite previamente anunciada dos bombardeios norteamericanos em Bagdá (quando da deflagração oficial da guerra entre EUA e Iraque), os programas interativos intitulados Big Brother, No Limite, Casa dos Artistas, Pop Stars, O Aprendiz, as campanhas (que divulgam as vantagens dos transgênicos e as pesquisas com células tronco) encarnam a valorização do exercício de eliminação nas existências particulares.

A eliminação, neste processo de desterritorialização da violência, encontra-se incitada pelas práticas de consumo e absorvida pela subjetividade capitalística. A relação entre eliminar e consumir atravessa as atitudes moleculares, não apenas pela excitação ao poder de compra e de aquisição de produtos-mercadorias, mas pelas posturas subjetivantes geradas com a equivalência do eliminar aos atos de gastar, destruir, liquidar. Ela traz possibilidades de instituição de uma nova moral, sustentando uma concepção de mundo, em que as noções de sujeito, de indivíduo, de humano e de vida (unidade orgânica) se diluem, instituindo práticas que operam por índices de prestígio, de eficácia, de felicidade e do bemestar, mensurados por cotações de ações, pela velocidade da informação e pela aquisição de produtos-mercadorias. A efemeridade do produto-mercadoria, vinculada às condutas correspondentes à concepção de felicidade e de consumo, desliza para significados que

\begin{tabular}{|c|c|c|c|c|}
\hline Govista Dialectus & Ano 2 & n.7 & Setembro - Dezembro 2015 & p. $127-146$ \\
\hline
\end{tabular}


implicam novos valores e regras num gradiente oscilante entre eliminação e extermínio da vida.

O consumo, para Deleuze e Guattari, encontra-se ligado a um processo de produção, o qual está assinalado por conexões de fluxos, por disjunções e por conjunções. Ele se distingue do consumo proposto por Baudrillard (1970), que procura definir a sociedade segundo uma lógica interna de termos pertinentes a um processo de subjetivação. Os termos utilizados por Baudrillard coincidem com os eixos (Significante, Capital e Ser) da subjetividade capitalística lançada por Deleuze e Guattari.

Além do exercício de consumo como um novo recurso de constrangimento em que a ordem é gastar, a eliminação encontra-se relacionada aos traços das sociedades de controle e à sobrecodificação da existência pelo capital financeiro. Deleuze (1992, p.223) aponta, no processo de atualização do capitalismo, os componentes demarcadores da passagem das sociedades disciplinares para as sociedades de controle, cujas técnicas e tecnologias orientamse para incrementação desse processo de subjetivação. Isso quer dizer que não há mais a necessidade da distribuição cartesiana de espaço-tempo voltada para o trabalho e para a produção característica das sociedades disciplinares. Há uma modulação contínua, que aciona uma alma gás, substituindo as rígidas fronteiras das fábricas (um sistema fechado) pelas flutuações da empresa (um sistema aberto). Ocorre um deslocamento da produção para o produto, para a venda, para o mercado: "É um capitalismo de sobreprodução".

Deleuze também salienta que o sujeito cede lugar para o espírito de equipe, o espírito da empresa para enfrentar desafios, instituindo uma rivalidade inexpiável modulada pelo salário por mérito no reconhecimento do melhor desempenho. Não há uma combinação sujeito-empresa ou indivíduo-empresa, há uma diluição do sujeito na empresa. A composição de equipes com alianças efêmeras é alimentada pela alma-gás, que incita e reconhece o mérito, quantificado em índices de resultados eficazes e em velocidades atingidas com a elaboração de estratégias baseadas na eliminação dos obstáculos para sua obtenção. Nesses movimentos, também desaparecem as noções de indivíduo, de identidade/identificação e de trabalho, produzindo novos códigos. Os indivíduos viram cifras, tornando-se dividuais, conformando banco de dados e de informações. As ações são monitoradas e codificadas em informações, engrossando os bancos de empresas através de filtros, que distribuem e agrupam caracteres orientados para produção de novas demandas, bem como para oferta de produtos e serviços. Os próprios perfis pessoais, divulgados nas redes sociais, servem de informações para os procedimentos seletivos das empresas que, sempre pautadas pelo desempenho,

\begin{tabular}{|c|c|c|c|c|}
\hline QRovista Dialectus & Ano 2 & n.7 & Setembro - Dezembro 2015 & p. $127-146$ \\
\hline
\end{tabular}


conjugam atitudes de risco, iniciativas e contatos (indicados pelo número de amigos) com as suas exigências para conquista de mercado.

O verbo deletar provém de dois estratos. A deleção, no estrato biológico, realiza uma supressão de segmentos operada por movimentos descontínuos, saltos e desencontros, trazendo uma potência de diferenciação na cadeia genética. A deleção carrega uma potência afirmativa pelo embaralhamento ${ }^{11}$. Quando extraído dos estratos biológicos e arranjado com componentes dos estratos informatizados, o verbo deletar adquire um novo sentido. Os estratos informatizados atravessam as máquinas computacionais e comunicacionais que processam códigos em informações. Elas armazenam esses códigos em uma área física (memória) acessada por um conjunto de comandos. A destruição, o apagamento desses códigos da memória que passam a ser considerados resíduos, aumenta a velocidade e a eficácia do processador na obtenção das informações dirigidas a resultados pré-determinados. $\mathrm{O}$ ato de deletar está diretamente ligado ao código-informação e ao desempenho. Ele perde sua potência afirmativa e criadora presente na genética, significando um tipo de ação válida para os dados, para códigos informatizados e para as relações vividas. A palavra delete corresponde a um comando que realiza a operação de apagar a informação do computador. Ela ganhou uso corriqueiro pelo verbo deletar, sendo utilizado em larga escala para designar o ato de apagar, extinguir, fazer desaparecer todos os vestígios considerados erros, entraves, retirando os registros da memória numa espécie de amnésia. Este ato encarna condutas, referindo-se a relações que remetem a uma espécie de vácuo afetivo assinalado pela destruição do sinal e pela extinção da existência. O deletar envolve os movimentos de reterritorialização do capital produzidos pela conjugação de fluxos direcionados a comandos capazes de aumentar a velocidade e o desempenho. As máquinas informacionais e comunicacionais garantem a reprodução das práticas de deletar em vários territórios. Essas ações aparecem na organização das equipes, reproduzindo as expectativas das sociedades de controle através da alma-gás apontadas por Deleuze (1992). Seus traços também permeiam o crime organizado, determinando uma hierarquia para o tráfico, os rituais de expiação para a aceitação de novos integrantes pelas gangues, as práticas de bullying como um

\footnotetext{
${ }^{11}$ Na genética, o termo deleção é usado para rearranjos não equilibrados no conjunto cromossômico. "A deleção resulta em desequilíbrio do cromossomo por perda de um segmento cromossômico. Uma deleção pode ser terminal ou intersticial. As deleções podem originar-se por quebra cromossômica e perda do segmento acêntrico. Em alguns casos, as deleções ocorrem por um crossing-over (recombinação que aumenta a diversidade genética pelo reembaralhamento dos genes) desigual entre cromossomos homólogos desalinhados ou cromátides-irmãs."
}

\begin{tabular}{|c|c|c|c|c|}
\hline QRovista Dialectus & Ano 2 & n.7 & Setembro - Dezembro 2015 & p. $127-146$ \\
\hline
\end{tabular}


comportamento recorrente em larga escala, especialmente nas escolas ${ }^{12}$. A eliminação é exercida pelo deletar em jogos, filmes, vídeos e músicas com a disseminação dos valores winner-loser ${ }^{13}$, balizando o critério do mérito que se sobrepõe aos termos e valores modernos. $\mathrm{O}$ deletar responde às novas demandas e abarca códigos relacionados à incorporação da atualização do capital no processo subjetivante, pelo qual as pessoas promovem-se reproduzindo as posturas requisitadas pela empresa.

Nessa trajetória, as ações e as condutas passam a operar por cotações e índices, reproduzindo os mecanismos do capital financeiro. As estratégias intensificam-se, modulando o eliminar e o deletar em exterminar. Elas permeiam diferentes territórios existenciais (do funcionamento da empresa às chacinas escolares, passando pelas redes sociais e pelos jogos digitais), esgarçando os limites do capitalismo. A definição da alma-gás, que engendra as sociedades de controle, indica os investimentos subjetivos atuais. As relações entre capital filiativo e capital de aliança, entre a produção capitalista e a produção não-capitalista possibilitam percorrer os movimentos de extensão do capitalismo. Nesses movimentos, situase a diferença entre esquizofrenia-processo e esquizofrenia-entidade em que vetores de reterritorialização desembocam nos microfascismos e nas linhas de destruição. Movimentos de reterritorialização pelo controle e seus efeitos são marcados na promoção de celebridades em empresários reconhecidos (e vice-versa), nos elementos arranjados em jogos que sobrecodificam posições em condutas reprodutoras de novas regras, significando a eliminação em mérito e em prestígio. As chacinas escolares (Columbine e Realengo) possibilitam detectar componentes divergentes das explicações e das patologizações recorrentes nos discursos especializados, ao serem relacionadas aos intoleráveis produzidos pelas sociedades atuais e convertidos em linhas de morte. Os vetores do eliminar, deletar e exterminar assinalam os movimentos de reterritorialização do capitalismo inseparáveis da subjetividade que garante sua ampliação e reprodução atuais.

A potência da eliminação pelo selecionar sinaliza traços de um novo modo de vida que se anunciam com a experimentação de um corpo capaz de fugir da organização disciplinar e de suas estratificações. Nessas desterritorializações, agenciamentos e alianças, mesmo efêmeros, carregam uma força ativa e criadora presente no uso minoritário das máquinas comunicacionais, informacionais, científicas, sociais, políticas... Agenciamento e

${ }^{12} \mathrm{O}$ bullying diverge dos valores morais pautados pelo respeito à condição humana, sendo considerado uma conduta violenta por ofender, ridicularizar, destruir pertences, agredir com palavras e/ou atos.

${ }^{13}$ A expressão, traduzida por ganhador-perdedor, vencedor-fracassado, será mantida em inglês porque ela é fortemente disseminada neste idioma, principalmente, entre os jovens nos rituais de promoção e/ou ridicularização promovidos nos territórios identitários.

\begin{tabular}{|l|l|l|l|l|}
\hline Q Revista Oialectus & Ano 2 & n.7 & Setembro-Dezembro 2015 & p. $127-146$ \\
\hline
\end{tabular}


ritornelo são enfatizados na demarcação de linhas de fuga. O selecionar corta fluxos constitutivos de agenciamentos, cuja dimensão ética-estética vem afirmar a singularidade, desdobrando-se em um salto para a vida ao ampliá-la, transbordando as escalas e os limites modernos, humanos e antropomórficos. Nesta dimensão, a produção de um novo sentido está ligada a uma outra noção de corpo, um corpo agenciamento orgânico-inorgânico, concebido por ações e paixões capazes de desembocar em uma nova composição de mundo.

Os movimentos de desterritorialização assinalados pelo selecionar desfazem o organismo, o qual delimita a vida ao modo moderno circunscrito pela representação. A relação entre as estratificações e o plano de consistência traz uma potência de criação, uma dimensão ética e estética capaz de gerar novos estilos de vida, disparada por desterritorializações positivas que se consolidam em conexões e conjugações afirmativas e singulares. A seleção percorre linhas de desestratificação do corpo, considerado unidade biológica, segundo distribuição binária da matéria: orgânica e inorgânica. Nesse movimento, o borramento das fronteiras, decorrente da fragmentação e da molecularização do corpo, produz uma abertura que carrega a emergência de um corpo químico-físico, numa espécie de involução, cujos acoplamentos demarcam vetores orientados ao infinitamente pequeno e ao infinitamente grande. A experimentação desse corpo mutante e em composição a cada conexão estabelecida marca o selecionar e a potência da eliminação em devires e agenciamentos constitutivos de processos de singularização. Ela é detectada plasticamente pelo devir silício do carbono com o cruzamento das máquinas tecnológicas que se orientam para a diluição do $e u$, do atributo humano, das fronteiras entre natural-artificial e real-digital. Um movimento de desestratificação desfaz a vida análoga a um corpo biologizado e restrita ao domínio dos viventes enunciados pelo pensamento moderno. Os limites que a estratificam são transformados, rompidos. A vida vem ganhando uma forma operada em escala quântica, estabelecendo novas relações entre componentes que a definem. Elementos inorgânicos, ao entrarem nessas relações, ligam-se a forças desterritorializadas, apontando para consolidação de um corpo num devir molecular que lhe confere nova consistência.

Deleuze e Guattari (1992, p. 200) salientam que "mesmo não viventes ou, antes, não orgânicas, as coisas têm um vivido porque são percepções e afecções". Também nos estratos científicos, as mudanças de dimensões levam ao embaralhamento das fronteiras entre orgânico e inorgânico, modificando a apreensão e a percepção da vida. O selecionar efetua-se em um modo de transitar por essa superfície, aqui denominada corpo composição orgânicainorgânica, referindo-se a esse corpo químico-físico, efeito do processo de quantização no

\begin{tabular}{|l|l|l|l|l|}
\hline Qevista Dialectus & Ano 2 & n.7 & Setembro-Dezembro 2015 & p. 127-146 \\
\hline
\end{tabular}




\section{ELIMINACÃO E DESLOCAMENTOS DA VIOLÊNCIA: UMA...}

Gisele Gallicchio

qual se detectam velocidades, relações, ligações e componentes em termos distintos dos enunciados biológicos e das associações mecânicas. Uma experimentação em que fluxos e linhas tendem para emergência de diferentes maneiras de existir ao ganhar consistência e definir formas moleculares distribuídas em uma superfície disjuntiva, conjugando-se sem totalizar nem homogeneizar. Dimensões vividas articulam-se à eliminação num trânsito por esse corpo processual e maquínico que vem assinalar a vida imanente.

Uma potência política da eliminação se esboça com a aproximação do selecionar à simpatia (tomada de Hume por Deluze), percorrendo eventos recentes relacionados à utilização da internet nas mobilizações de grupelhos que ocupam as ruas de Madri, Londres, Egito, Brasil.... As novas escalas, provocadas pelo devir silício, geram afetos e afecções, suscitando uma micropolítica, cujo mapa merece maior demora na constituição de um corpo compósito (orgânico-inorgânico) simultaneamente quântico e planetário.

Uma vida intensiva, um pensamento imanente. Diferentes modos a recortam. Uma forma tende a predominar. Movimentos e linhas produzem um acontecimento em devir que podem definir um sentido à eliminação.

\section{REFERÊNCIAS}

ARENDT, Hannah. Sobre a violência. Tradução de André Duarte. Rio de Janeiro: Civilização Brasileira, 2009.

BENJAMIN, Walter. Documentos de cultura, documentos de barbárie: escritosescolhidos.Tradução de Willi Bolle e outros. São Paulo: Editora Cultrix, 1986.

BAUDRILLARD, Jean. Modernité. In: Biennale de Paris: la modernité ou l'esprit du temps. Paris, Editions L'Equerre, 1982.

A sociedade de consumo. Tradução de Artur Mourão. Lisboa: Edições 70, 1970.

DELEUZE, Gilles. A filosofia de Kant. Lisboa: Ed. 70. Lisboa, s/d.

Conversações. Tradução de Peter Pál Pelbart. Rio de Janeiro: Ed. 34, 1992.

Bergsonismo. Tradução de Luiz B.L. Orlandi. São Paulo: Ed. 34, 1999.

A lógica do sentido. Tradução de Luiz Roberto Salinas Fortes $4^{a}$. ed. São

Paulo: Editora Perspectiva, 1998.

DELEUZE, Gilles \& GUATTARI, Félix. O que é a filosofia? Tradução Bento Prado Jr. e Alberto A. Muñoz. Rio de Janeiro: Ed.34, 1992.

LYOTARD, Jean-François. O pós-moderno. Tradução de Ricardo Corrêa Barbosa. Rio de Janeiro: José Olympio, 1988.

\begin{tabular}{|l|l|l|l|l|}
\hline Revista Dialectus & Ano 2 & n.7 & Setembro-Dezembro 2015 & p. 127-146 \\
\hline
\end{tabular}


MARCONDES, Danilo. Textos básicos de ética - de Platão a Foucault. $2^{\mathrm{a}}$.ed. Rio de Janeiro: Zahar, 2007.

SANTIAGO, Homero. Spinoza: Superstição e a ordem moral do mundo. In: MARTINS, André (Org.) O mais potente dos afetos: Spinoza e Nietzsche. São Paulo: Martins Fontes, 2009, p. 171-212.

WIEVIORKA, Michel. La violance. Paris: Hachette Littératures, 2005.

Em que mundo vivemos? São Paulo: Ed. Perspectiva, 2006. 